\title{
PREZENCJA JAKO KRYTERIUM DECYZJI PERSONALNYCH
}

DOI: $10.33141 /$ po.2020.09.04

\section{Katarzyna Wojtaszczyk}

\section{Wprowadzenie}

$\mathbf{N}$ a wygląd człowieka składa się jego fizyczność, obejmująca takie zmienne, jak: budowa, kształt i masa ciała czy wzrost oraz prezencja, czyli atrybuty niezwiązane bezpośrednio $\mathrm{z}$ charakterystykami ciała. O prezencji stanowią zatem: ubiór, fryzura, makijaż czy inne obserwowalne efekty dbałości o siebie (Szymaniak-Kostrzewska, 2016, s. 47). Tak rozumiana prezencja pełni szereg funkcji, które istotne są nie tylko z perspektywy jednostki i jej życia prywatnego oraz zawodowego, ale również z punktu widzenia organizacji, której jest członkiem. Prezencja pracowników jest widocznym aspektem kultury organizacyjnej oraz narzędziem kształtowania wizerunku firmy (Altkorn, 1999, s. 11). Nie dziwi zatem, na co wskazują wyniki badań empirycznych (Paprzycka, Orlik, 2015; Sobczak, Smith, 2016), że przynajmniej część decyzji zarządczych dotyczących obszaru zarządzania zasobami ludzkimi $(z z l)^{1}$ podejmowanych jest pod wpływem oceny na podstawie wyglądu kandydata do zatrudnienia lub pracownika. Ponadto podejmowanie decyzji ze względu na wygląd (czy węziej - prezencję) odzwierciedla „ludzką" stronę rozwiązywania problemów organizacyjnych. W rzeczywiście występujących sytuacjach zachowania decydentów nie zawsze bowiem pokrywają się z zaleceniami o racjonalności i obiektywnych kryteriach oceny.
Przegląd Organizacji, Nr 9(968), 2020, s. 26-33

www.przegladorganizacji.pl

๑) Towarzystwo Naukowe Organizacji i Kierownictwa (TNOiK)
Celem artykułu jest pokazanie istoty prezencji oraz jej roli jako jednego z kryteriów decyzyjnych w obszarze zarządzania zasobami ludzkimi. Postawiono (w odniesieniu do badań empirycznych) następujące pytania badawcze:

- Czy badani są mocno zaangażowani w dbałość o własną prezencję?

- Jaki jest stopień zróżnicowania zespołów pracowniczych ze względu na dbałość o prezencję?

- Czy istnieje związek pomiędzy dbaniem o prezencję a wywiązywaniem się pracownika $\mathrm{z}$ obowiązków zawodowych?

- Czy kierownicy powinni mieć prawo do ingerowania w prezencję pracowników?

- Czy przy podejmowaniu decyzji personalnych bierze się pod uwage prezencję zatrudnionych?

Do realizacji celu wykorzystano dwie metody badawcze: (1) tradycyjny przegląd literatury, (2) badania ankietowe. Tradycyjny przegląd literatury posłużył do opracowania sekcji teoretycznych poświęconych prezencji oraz decyzjom w zarządzaniu zasobami ludzkimi. Ze względu na interdyscyplinarność zagadnienia „prezencji” w tekście odwołano się nie tylko do prac z dziedziny nauk społecznych, ale i do publikacji autorstwa przedstawicieli nauk humanistycznych, medycznych oraz ścisłych. W rozważaniach opracowanych 
na podstawie przeglądu literatury uwzględniono też dane zastane. Wykorzystano głównie dane pochodzące $\mathrm{z}$ raportów i doniesień $\mathrm{z}$ badań zamieszczonych $\mathrm{w}$ zasobach Internetu. Badania ankietowe o charakterze sondażowym realizowane były w latach 2017-2018. Przeprowadzono dwa badania: w pierwszym wzięli udział kierownicy, w drugim - osoby niepełniące funkcji menedżerskich. Wyniki badań zagregowano.

Artykuł ma charakter teoretyczno-empiryczny. Adekwatnie do terminów zawartych w jego tytule rozważania rozpoczęto od pokazania istoty prezencji oraz krótkich charakterystyk jej składowych. W kolejnej sekcji skoncentrowano się na specyfice decyzji z obszaru zarządzania zasobami ludzkimi. Część empiryczną pracy otwiera prezentacja metodyki przeprowadzonych badań własnych. Ostatni punkt zawiera rezultaty zrealizowanych badań ankietowych.

Tematyka opracowania ma charakter interdyscyplinarny. Wpisuje się w problematykę stylu życia (którego jednym $\mathrm{z}$ wymiarów jest prezencja) oraz rozważania dotyczące racjonalności decyzji. Artykuł dotyka także spraw związanych z: wypełnianiem funkcji personalnej, dyskryminacją w zatrudnieniu (ze względu na wygląd), atrakcyjnością interpersonalną człowieka, kształtowaniem marki czy wizerunku organizacji oraz marki osobistej. Do wszystkich tych zagadnień starano się w pracy nawiązać. Niestety, ze względu na formułę artykułu, która nie pozwala na prowadzenie szczegółowych (a tym samym obszernych) rozważań, część $\mathrm{z}$ wymienionych zagadnień jedynie zasugerowano.

\section{Istota, funkcje i składowe prezencji}

$\mathbf{S}$ łowo „prezencja”, pochodzące $\mathrm{z}$ łaciny, oznaczało pierwotnie „przytomność umysłu” (Krasnowolski, Niedźwiedzki, 1920). Potocznie pod pojęciem tym rozumie się ogół cech zewnętrznych, na podstawie których ocenia się człowieka. Zgodnie z ujęciem słownikowym, prezencja jest synonimem zewnętrzności człowieka, jego powierzchowności, aparycji bądź wyglądu (Dąbkowski, Marcjanik, 2002, s. 281). Psychologowie podkreślają jednak, że prezencja rozumiana jako szereg takich zmiennych (niezwiązanych bezpośrednio z charakterystykami ciała), jak: ubiór, fryzura, makijaż czy inne obserwowalne efekty dbałości o siebie, to tylko jeden $\mathrm{z}$ aspektów wyglądu zewnętrznego (Szymaniak-Kostrzewska, 2016, s. 47). Drugim wymiarem wyglądu jest „fizyczność” czy też "cielesność” człowieka obejmująca budowę ciała, wzrost, kształt, masę, stan, wygląd i kolor skóry, włosów, oczu.

Prezencję zdefiniować można zatem jako sposób, w jaki przyozdabia się ciało. Jest ona składową tożsamości wtórnej człowieka, czyli zmienną, którą jednostka może samodzielnie kształtować i która ewoluuje w czasie. Prezencja jest tym samym wymiarem stylu życia jednostki. Prezencja uważana jest także za komponent kapitału erotycznego człowieka. Zgodnie z koncepcją tegoż kapitału (autorstwa C. Hakim (2010, s. 500)), na prezencję składają się: sposób ubierania się, makijaż, używane perfumy, biżuteria i inne noszone do stroju ozdoby, fryzura, akcesoria. Zdaniem A. Strzeleckiej (2002, s. 70), zaangażowanie w dbałość o prezencję przypisywane jest częściej kobietom niż mężczyznom. Na podstawie badań empirycznych stwierdzić można, że troska ta (w odniesieniu do kobiet) przejawia się w: noszeniu sukienek lub spódnic, robieniu makijażu, malowaniu paznokci, balsamowaniu ciała, farbowaniu włosów, depilowaniu nóg, noszeniu biżuterii, podkreślaniu strojem figury, chodzeniu do fryzjera.

Prezencja pełni funkcje informacyjne: informuje o statusie społeczno-ekonomicznym, stanie cywilnym, zawodzie i wykonywanych przez człowieka zajęciach (Hogan i in., 2007, s. 70). Jest ona jedną z ważniejszych determinant zadowolenia z życia (Frederick i in., 2016, s. 543-549), czynnikiem atrakcyjności interpersonalnej oraz społecznej jednostki (Wojciszke, 2002, s. 278). Prezencja to też swoisty kod o charakterze etykietalnym (Jacko, 2007, s. 446-460), dzięki któremu jednostka jest w stanie pokazać własny stosunek do obowiązujących norm społecznych. Prezencję należy więc uważać za narzędzie autoprezentacji (Trzeciak, 2015, s. 213-218).

Z punktu widzenia organizacji prezencja zatrudnionych jest elementem wizerunku przedsiębiorstwa (Karaosmanoglu, 2006, s. 75). Mimo że podstawowe znaczenie ma tu prezencja tzw. pracowników bezpośredniego kontaktu, to wygląd członków organizacji wpłynąć może też na opinię klienta dotyczącą firmy jako całości. Stąd też coraz więcej instytucji wprowadza tzw. dress code. Choć reguły dress code odnoszą się zwykle do garderoby i noszonych dodatków, to obejmować mogą także wytyczne związane $\mathrm{z}$ makijażem, uczesaniem czy zarostem. Badania empiryczne z King`s College London wskazują, iż standardy dotyczące ubioru i wyglądu pracowników przynoszą organizacjom szereg takich korzyści, jak: dopasowanie prezencji pracownika do marki organizacji, profesjonalizację stanowiska pracy, dbałość o kwestie zdrowia i bezpieczeństwa, stworzenie poczucia tożsamości organizacyjnej (Nath i in., 2016, s. 1).

Dodać warto, że prezencja pracowników wykorzystywana bywa $\mathrm{w}$ działaniach promocyjnych zarówno wewnątrz, jak i na zewnątrz organizacji. Przykładami mogą być identyfikatory, publikowanie zdjęć pracowników w Intranecie, newsletterach, na internetowej stronie domowej czy funpage'u pracodawcy. Prezencję uznać zatem należy za narzędzie komunikacji marketingowej (Szymoniuk, 2011, s. 442-451) oraz jeden z fizycznych artefaktów kultury organizacyjnej (Zbiegień-Maciąg, 1999, s, 44-51).

Relatywnie najczęściej wymienia się trzy charakterystyki prezencji (Czaplińska, 2015, s. 20-22): (1) strój, (2) makijaż oraz (3) fryzurę.

Pierwszy z wymienionych elementów prezencji - strój, jako pewnego rodzaju regulator stosunków międzyludzkich, od zawsze odgrywał rolę w życiu jednostek i całych społeczeństw (Rosen-Przeworska, 1948-1949, s. 297). Ubranie stanowi wskazówkę do „interpretacji” noszącej je osoby (Giddens, 2012, s. 138). W efekcie garderoba jest łączona $\mathrm{z}$ tożsamością społeczną jednostki i, poprzez wysyłane pozawerbalne sygnały, pełni funkcję komunikacyjną (Kujawska-Kot, 2018, s. 29-53). Ubranie jest ponadto środkiem „określania się w społeczeństwie” (McLuhan, 2004, s. 173) oraz narzędziem wprowadzania człowieka w przestrzeń społeczną (Joubert, Stern, 2006, s. 7).

Rozważając problematykę stroju z punktu widzenia nauki o organizacji, zwraca się zwykle uwagę na zasady dotyczące ubioru pracowników. Wyróżnia się przynajmniej kilka rodzajów ubrań formalnych (Sobczak, Smith, 
2016): business casual, smart casual, boardroom formal, przy czym, czego dowodzą analizy empiryczne, noszenie formalnej odzieży sprzyja myśleniu abstrakcyjnemu (Slepian i in., 2015, s. 661-668). Warto dodać, że dywagacje poświęcone ubiorowi odnaleźć można w jednej z prac A. Smitha - „Teorii uczuć moralnych”. Zdaniem tego szkockiego myśliciela, strój: odzwierciedlać może przynależność człowieka do konkretnej klasy; pokazuje osobowość jednostki; może stać się powodem odrzucenia jednostki przez grupę (Smith, 1989, s. 286-291).

Z kolei makijaż, będący najbardziej popularną formą modyfikacji ciała, ma głównie na celu tuszowanie mankamentów oraz podkreślanie cech urody, które pozwalają wpisać się $\mathrm{w}$ panujące wzorce piękna. Makijaż (jeśli nie jest permanentny), podobnie jak ubiór, „charakteryzuje się chwilowością i zmiennością, daje możliwość wyrazu, ale jednocześnie niesie możliwość zmiany" (Jakubowska, 2009). Kosmetyki pozwalają manipulować atrakcyjnością fizyczną oraz oddziałują na psychikę i podnoszą pewność siebie (Kosmala i in., 2019, s. 216); uwydatnione makijażem kości policzkowe są oznaką dojrzałości. Uważa się, że kobiety stosujące makijaż (w porównaniu z tymi niemalującymi się) cechuje większa samoświadomość publiczna (Kościński, 2007, s. 36-40). Badania potwierdzają, że kobiety w pełnym makijażu odbierane są jako atrakcyjniejsze od tych nieumalowanych (Kosmala i in., 2019, s. 217). Makijaż jest istotny z punktu widzenia życia zawodowego. W przypadku pewnych zawodów (np. sprzedawcy kosmetyków) bywa uważany za obowiązkowy. Konsultanci podkreślają, iż makijaż do pracy powinien skupiać uwagę rozmówcy na oczach: „podkreślanie oczu makijażem to podkreślanie własnej wartości intelektualnej i duchowej" (Szcześniak-Kosiorek, 2020).

Kolejną zmienną prezencji jest fryzura, będąca ważnym elementem składającym się na pierwsze wrażenie (Hogan i in., 2007, s. 72-74). Zdrowe włosy odzwierciedlają ogólny stan zdrowia; mężczyzna o krótkich włosach jest przez kobiety postrzegany jako atrakcyjniejszy, bardziej męski, inteligentniejszy i o atrakcyjniejszej osobowości niż ten sam mężczyzna o włosach średnich, a tym bardziej długich (Kościński, 2009, s. 34). Konsultanci biznesu czy doradcy budowania marki osobistej podkreślają, że w środowisku pracy (w przypadku kobiet) najlepiej sprawdza się fryzura średniej długości, która symbolizuje kobietę silną, wymagającą, dynamiczną, nastawioną na działanie (Szcześniak-Kosiorek, 2020).

Przedstawione powyżej rozważania na temat prezencji pokazują, że jest ona przedmiotem zainteresowań nauk humanistycznych, medycznych, społecznych oraz ścisłych. Choć prezencją osób poszukujących zatrudnienia czy pracowników zajmują się także praktycy (doradcy personalni, coachowie czy tzw. konsultanci biznesu), to tematyka ta nie jest szeroko podejmowana przez specjalistów z zakresu zarządzania. Przyczyną takiego stanu rzeczy może być przeświadczenie, że wszelkie decyzje zarządcze winny charakteryzować się jak największym stopniem racjonalności. $\mathrm{Z}$ tego punktu widzenia prezencja nie wpisuje się w zestaw obiektywnych kryteriów oceny, więc nie powinna stanowić o podejmowanych decyzjach zarządczych. Sugerowanie się prezencją aplikującego czy członka organizacji może być także traktowane jako łamanie zasady równego traktowania w zatrudnieniu i dyskryminowanie bezpośrednie ze względu na wygląd (appearance discrimintaion). Ponadto ocena wyglądu, która dotyczy częściej kobiet niż mężczyzn, skutkować może dyskryminacją ze względu na płeć (Cavico i in., 2012, s. 796). Między innymi z tego powodu, na co wskazują rezultaty badań empirycznych, osoby, które nie są szczególnie atrakcyjne pod względem prezencji, znajdują się w gorszej sytuacji na rynku pracy i trudnej jest im osiągnąć sukces zawodowy (Gehrsitz, 2014, s. 269-287).

\section{Decydowanie i specyfika decyzji personalnych}

D odejmowanie decyzji definiowane jest jako proces świadomego (nielosowego) wyboru jednego $\mathrm{z}$ rozpoznanych i uznanych za możliwe wariantów przyszłego działania lub „postanowienie o podjęciu określonego działania” (Bolesta-Kukułka, 2003, s. 43). W praktyce zarządzania wybór określonego wariantu rozwiązania cechuje się zwykle ograniczoną racjonalnością, towarzyszącą rozwiązaniom zadowalającym (Mikołajczyk, 1994, s. 30). Stosowanie rozwiązań satysfakcjonujących bywa koniecznością związaną z występowaniem obiektywnych i subiektywnych barier ograniczających racjonalność (Jakubowska, 2008, s. 66).

W literaturze z zakresu zzl podkreśla się, że decydowanie dotyczy każdej z subfunkcji kadrowych (Sobocka-Szczapa, 2014, s. 104), „profesjonalizacja decyzji personalnych powinna być jedną z głównych zasad zarządzania organizacją" (Sajkiewicz, 1999, s. 17), a zzl winno charakteryzować się obiektywizmem (Król, 2006, s. 75-76). Jednak w praktyce organizacji „ludzkie” ograniczenia związane $\mathrm{z}$ racjonalnością rzutują nie tylko na sam wybór wariantu rozwiązania, ale i stosowane kryteria oceny. Mimo że nauki o zarządzaniu postulują używanie mierników związanych z maksymalizacją bądź optymalizacją (Bolesta-Kukułka, 2003, s. 134), to decyzje organizacyjne oparte bywają o kryteria niemierzalne, niepozwalające na jednoznaczną ocenę (Wrzalik, 2013, s. 45) lub wręcz o kryteria nie w pełni przez decydenta uświadomione (Holska, 2016, s. 245-250). W efekcie ocena rozwiązań nie zawsze jest wolna od błędów, które w przypadku zzl przejawiają się: niedostatkiem obiektywizmu, przenoszeniem własnych cech na osoby oceniane, ewaluacją na podstawie pierwszego lub ostatniego wrażenia, „efektem aureoli”, „efektem atrybucji” czy kierowaniem się stereotypami, które dotyczyć mogą fizyczności lub prezencji człowieka.

Częściowym potwierdzeniem decydowania na podstawie prezencji mogą być wyniki monitoringu ogłoszeń o pracy z roku 2009 (Kędziora i in., 2009, s. 11-15). Zgodnie z nimi, w przypadku $2 \%$ anonsów stwierdzić można nieprawidłowości, które prowadzić mogą do naruszenia zasady równego traktowania w zatrudnieniu ze względu na wymóg miłego, sympatycznego czy młodego wyglądu. Analizy E. Paprzyckiej i D. Orlik (2015, s. 15) dowodzą z kolei, że elegancki ubiór i stonowany makijaż kandydatki do zatrudnienia to atuty osób aplikujących, które brane są pod uwagę już w etapie wstępnej selekcji. Badania zrealizowane przez CareerBuilder (Sobczak, Smith, 2016) pokazują ponadto, że mniejsze szanse na awans mają między innymi ci, którzy: ubierają się do pracy w sposób prowokacyjny (44\% badanych); noszą 
niewyprasowane ubrania (43\% odpowiedzi); mają kolczyki w innych (widocznych) miejscach niż uszy (32\%).

Zaprezentowane powyżej dane odnoszą się do podejmowania decyzji personalnych tylko w zakresie pozyskiwania i awansowania pracowników (na podstawie prezencji). Warto zatem odwołać się do rezultatów innych badań empirycznych, w których zgromadzono informacje na temat roli prezencji (kandydata lub pracownika) w decydowaniu.

\section{Metoda i próba badawcza}

$\mathbf{Z}$ wiązki prezencji z decyzjami kierowniczymi stanowiły jeden z obszarów badań własnych poświęconych poznaniu opinii pracowników i kierowników na temat stylu życia podwładnych jako kryterium podejmowania decyzji kierowniczych. Koncepcja tych badań (określenie celu badań i sposobu doboru respondentów, wybór metody i techniki badawczej, opracowanie narzędzi badawczych) została przygotowana przez trzyosobowy zespół, którego członkiem była autorka niniejszego artykułu. Zespół badawczy dokonał także opracowania i analizy uzyskanych wyników. W badaniach tych prezencję (potraktowaną "całościowo" jako sposób ubierania się, fryzurę, makijaż, tatuaże i noszoną biżuterię) nazwano wyglądem.

Ankietowymi badaniami sondażowymi, realizowanymi w latach 2017-2018, prowadzonymi techniką CAWI, objęto 1002 kierowników oraz 1000 osób niezajmujących stanowisk kierowniczych, zatrudnionych $\mathrm{w}$ organizacjach na terenie
Polski. Wykorzystano dwa kwestionariusze ankiety: jeden z nich skierowano do menedżerów, drugi - do pracowników, którzy nie zadeklarowali pełnienia funkcji kierowniczych. Każdy z formularzy składał się z 20 pytań zamkniętych i metryczki. Zawarte w obu kwestionariuszach pytania były zbliżone - zmodyfikowano jedynie formę pytań w zależności od tego, czy kierowane były do osób zarządzających czy pracowników wykonawczych. Analizując wyniki, wykorzystano statystyki opisowe oraz tabele kontyngencji.

Kwestionariusze dystrybuowane były przez zewnętrzne firmy specjalizujące się w realizacji badań społecznych. Dobór obu prób (nielosowy) oparty był na dostępności osób badanych dla zleceniobiorców. W niniejszym opracowaniu wykorzystano tylko część zgromadzonych danych (związanych z prezencją).

Formularze ankiety wypełniło nieco więcej kobiet niż mężczyzn (zarówno w przypadku kierowników, jak i pracowników wykonawczych). Relatywnie największe odsetki badanych reprezentują osoby w wieku od 31 do 40 lat (27\%); których staż pracy nie przekracza 5 lat (28\%) - tabela 1. Badani reprezentują mikro, małe, średnie oraz duże organizacje - odpowiednio: $20 \%, 36 \%$, 24\% i $20 \%$ ogółu ankietowanych.

Ponad połowa badanych $(56,2 \%)$ deklaruje, że jest osobą "mocno zaangażowaną” w dbałość o własny wygląd. W grupie tej jest nieco więcej kierowników niż pracowników wykonawczych (odpowiednio 60,1\% i 51,5\%), co potwierdzać może opinię J. Tylki (2012, s. 12), że nienaganny wygląd to jedna $\mathrm{z}$ charakterystyk współczesnego

Tabela 1. Charakterystyka badanych (dane w \%)

\begin{tabular}{|c|c|c|c|c|}
\hline & & Kierownicy & Pracownicy & Ogółem \\
\hline \multirow{2}{*}{ Płeć badanego } & Kobieta & 52 & 59 & 55 \\
\hline & Mężczyzna & 48 & 41 & 45 \\
\hline \multirow{5}{*}{ Wiek badanego } & Do 30 lat & 6 & 40 & 23 \\
\hline & $31-40$ lat & 25 & 28 & 27 \\
\hline & $41-50$ lat & 30 & 17 & 23 \\
\hline & $51-60$ lat & 26 & 10 & 18 \\
\hline & Powyżej 60 lat & 13 & 5 & 9 \\
\hline \multirow{4}{*}{ Staż pracy badanego } & Do 5 lat & 16 & 39 & 28 \\
\hline & $6-15$ lat & 38 & 34 & 36 \\
\hline & 16-25 lat & 26 & 17 & 21 \\
\hline & Powyżej 25 lat & 20 & 10 & 15 \\
\hline
\end{tabular}

Źródto: opracowanie własne

Tabela 2. Zróżnicowanie zespołów ze względu na dbałość o prezencję (dane w \%)

\begin{tabular}{|c|c|c|c|c|c|c|}
\hline Stopień zróżnicowania & \multicolumn{2}{|c|}{ Kierownicy } & \multicolumn{2}{|c|}{ Pracownicy } & \multicolumn{2}{|c|}{ Ogółem } \\
\hline Bardzo zróżnicowany & 18,8 & \multirow{2}{*}{\} 51,5} & 23,5 & \multirow{2}{*}{\} 61,3} & 21,1 & \multirow{2}{*}{\} 56,3} \\
\hline Średnio zróżnicowany & 32,7 & & 37,8 & & 35,2 & \\
\hline Mało zróżnicowany & 35,5 & \multirow{2}{*}{\} 46,9} & 23,3 & \multirow{2}{*}{\} 29,6} & 29,4 & \multirow{2}{*}{38,2} \\
\hline Jednolity & 11,4 & & 6,3 & & 8,8 & \\
\hline
\end{tabular}

Źródło: opracowanie wtasne (dane nie sumują się do 100\%, gdyż ponad $5 \%$ ogółu badanych nie umiało określić stopnia zróżnicowania zespołu i udzieliło odpowiedzi „trudno powiedzieć”) 
menedżera. Do dbałości o prezencję przyznaje się więcej badanych kobiet niż mężczyzn (63,0\% ankietowanych kobiet w porównaniu do 47,8\% mężczyzn). Ta informacja koresponduje z (cytowanymi wcześniej) wynikami badań A. Strzeleckiej (2002, s. 70) dotyczącymi przypisywania troski o prezencję głównie kobietom.

\section{Wyniki badań}

W ięcej niż połowa respondentów pracuje w zespołach (bądź kieruje zespołami), których członkowie „bardzo” lub „średnio” różnią się pod względem troski o strój czy fryzurę, przy czym zróżnicowanie to częściej dostrzegają pracownicy $(61,3 \%)$ niż osoby wypełniające funkcje menedżerskie $(51,5 \%)$ - tabela 2.

Zdaniem połowy ogółu badanych, dbałość o prezencję jest pozytywnie skorelowana $\mathrm{z}$ wywiązywaniem się $\mathrm{z}$ obowiązków w miejscu zatrudnienia (tab. 3). Zdecydowanie mniejszy odsetek ankietowanych (tylko 19,9\%) twierdzi, iż nadmierne koncentrowanie się na ozdabianiu ciała nie sprzyja pracy zawodowej. Istnieją istotne różnice w opiniach kierowników i osób niepełniących funkcji menedżerskich dotyczące negatywnego wpływu dbania o prezencję na wykonywane zadania oraz braku powiązania pomiędzy tymi zmiennymi.

Przeświadczenie o dodatniej współzależności między przywiązywaniem wagi do prezencji a wywiązywaniem się z zadań zawodowych może być powodem tego, że ponad połowa badanych menedżerów $(55,7 \%)$ wskazuje, że kierownik powinien mieć prawo do ingerowania $\mathrm{w}$ sprawy związane z ubiorem czy fryzurą zatrudnionego (tab. 4). Porównując odpowiedzi menedżerów i pracowników, stwierdzić można, iż ci drudzy w mniejszym stopniu zgadzają się na interweniowanie w ich styl życia, niż chcieliby tego przełożeni. Dodatkowo, im dłuższy staż pracy na stanowisku kierowniczym, tym większe przeświadczenie przełożonego o prawie do ingerowania w prezencję podwładnego.

Dane dotyczące ingerencji w prezencję zatrudnionych są zblizzone do wyników reprezentatywnego badania Pracuj. pl z roku 2019 (Skwarska, 2019). Wynika z niego, że choć zdaniem niemal 75\% badanych Polaków, w miejscu pracy powinna istnieć swoboda ubioru, to $55 \%$ ankietowanych pozytywnie ocenia wprowadzanie zasad dress code.

Zrealizowane badania pokazują ponadto, że prezencja pracownika bywa kryterium, na podstawie którego podejmowane są decyzje personalne (tab. 5). Mimo że więcej pracowników niż kierowników uważa, że wygląd jest jedną $\mathrm{z}$ determinant decyzji kadrowych, to ogólnie ponad połowa respondentów jest zdania, że prezencja jest czynnikiem oceny kandydatów do zatrudnienia bądź członków organizacji. Trzeba dodać, że aż 12,5\% ankietowanych kierowników nie umiało jednoznacznie stwierdzić, czy ich decyzje z obszaru zarządzania zasobami ludzkimi powiązane są z prezencją ocenianego kandydata lub podwładnego (przy 3\% pracowników wykonawczych). Oznaczać to może, iż sposób prezentowania się aplikanta lub pracownika stanowi nieuświadomione kryterium oceny.

Tabela 3. W jaki sposób wysoki poziom zaangażowania pracownika w dbałość o prezencję wptywa na wykonywanie przez niego obowiązków pracowniczych? (dane w \%)

\begin{tabular}{|c|c|c|c|}
\hline Charakter wpływu: & Kierownicy & Pracownicy & Ogółem \\
\hline Wpływa pozytywnie & 56,4 & 42,3 & 49,3 \\
\hline Wplywa negatywnie & 33,6 & 6,2 & 19,9 \\
\hline Nie ma wpływu & 2,0 & 39,1 & 20,5 \\
\hline
\end{tabular}

Źródło: opracowanie własne (dane nie sumują się do 100\%, bo około 10\% respondentów zaznaczyło odpowiedź „trudno powiedzieć”)

Tabela 4. Czy kierownik powinien mieć prawo ingerować w prezencję pracownika? (dane w \%)

\begin{tabular}{|c|c|c|c|c|c|c|}
\hline Opcje odpowiedzi: & \multicolumn{2}{|c|}{ Kierownicy } & \multicolumn{2}{|c|}{ Pracownicy } & \multicolumn{2}{|c|}{ Ogółem } \\
\hline Zdecydowanie tak & 11,4 & \multirow{2}{*}{\} 55,7} & 7,2 & \multirow{2}{*}{\} 31,5} & 9,3 & \multirow{2}{*}{\} 43,6} \\
\hline Raczej tak & 44,3 & & 24,3 & & 34,3 & \\
\hline Raczej nie & 19,4 & \multirow{2}{*}{\} 39,4} & 24,2 & \multirow{2}{*}{\} 58,1} & 21,8 & \multirow{2}{*}{\} 48,7} \\
\hline Zdecydowanie nie & 20,0 & & 33,9 & & 26,9 & \\
\hline
\end{tabular}

Źródło: opracowanie wtasne (dane nie sumują się do 100\% - 15\% ogółu badanych udzieliło odpowiedzi „trudno powiedzieć”)

Tabela 5. Czy przy podejmowaniu decyzji personalnych badany kierownik/bezpośredni przełożony respondenta bierze pod uwagę prezencję pracownika? (dane $\mathrm{w} \%$ )

\begin{tabular}{|c|c|c|c|c|c|c|}
\hline Opcje odpowiedzi: & \multicolumn{2}{|c|}{ Kierownicy } & \multicolumn{2}{|c|}{ Pracownicy } & \multicolumn{2}{|c|}{ Ogółem } \\
\hline Zdecydowanie tak & 11,9 & & 16,1 & & 14,0 & \\
\hline Raczej tak & 32,2 & \} 44,1 & 45,4 & \} 61,5 & 38,8 & \} 52,8 \\
\hline Raczej nie & 26,7 & & 21,9 & & 24,3 & \\
\hline Zdecydowanie nie & 16,8 & & 13,6 & 35,5 & 15,2 & \} 39,5 \\
\hline
\end{tabular}

Źródło: opracowanie wtasne (dane nie sumują się do 100\%, gdyż prawie 8\% ogółu badanych udzieliło odpowiedzi „trudno powiedzieć”) 
Tabela 6. Przeświadczenie kierownika o wpływie dbałości o prezencję na wykonywanie obowiązków zawodowych a stosowanie kryterium wyglądu przy podejmowaniu decyzji kadrowych (dane w \%)

\begin{tabular}{|l|c|c|c|}
\cline { 2 - 4 } \multicolumn{1}{c|}{} & \multicolumn{3}{c|}{$\begin{array}{c}\text { Wpływ zaangażowania pracownika w dbałość o prezencję } \\
\text { na wykonywanie przez niego obowiązków zawodowych }\end{array}$} \\
\cline { 2 - 4 } & Pozytywny & Negatywny & Brak wpływu \\
\hline Prezencja jest kryterium podejmowania decyzji & 44,8 & 1,3 & 12,3 \\
\hline Prezencja nie jest kryterium podejmowania decyzji & 11,0 & 5,0 & 20,4 \\
\hline
\end{tabular}

Źródło: opracowanie własne (dane nie sumują się do 100\%, gdyż nie wzięto pod uwagę odpowiedzi „trudno powiedzieć”)

Tabela 7. Zaangażowanie kierownika w dbałość o własną prezencję a stosowanie kryterium wyglądu przy podejmowaniu decyzji personalnych (dane w \%)

\begin{tabular}{|c|c|c|}
\hline & \multicolumn{2}{|c|}{ Zaangażowanie kierownika w dbałość o własną prezencję } \\
\hline & $\begin{array}{c}\text { Kierownik uważa się za osobę } \\
\text { mocno zaangażowaną w dbanie } \\
\text { o własną prezencję }\end{array}$ & $\begin{array}{c}\text { Kierownik nie uważa się } \\
\text { za osobę mocno zaangażowaną } \\
\text { w dbanie o własną prezencję }\end{array}$ \\
\hline Prezencja jest kryterium podejmowania decyzji & 42,6 & 18,9 \\
\hline Prezencja nie jest kryterium podejmowania decyzji & 16,7 & 18,8 \\
\hline
\end{tabular}

Źródto: opracowanie wtasne (dane nie sumują się do 100\%, gdyż nie wzięto pod uwagę odpowiedzi „trudno powiedzieć”)

Zgromadzone dane nie wykazały różnic w wypowiedziach kobiet i mężczyzn piastujących stanowiska kierownicze - prezencją aplikanta lub pracownika jako kryterium oceny rozwiązań w podejmowaniu decyzji kadrowych kieruje się $60,7 \%$ badanych kobiet - menedżerek oraz $62,7 \%$ mężczyzn na stanowiskach kierowniczych. Nie odnotowano współzależności między stażem na stanowisku kierowniczym a podejmowaniem decyzji na podstawie prezencji. Analiza danych z tabel kontyngencji pokazuje natomiast, że:

- Stosunkowo największy odsetek kierowników (44,8\%) to osoby, które, będąc przekonanymi o pozytywnej relacji pomiędzy dbałością o prezencję a wykonywaniem obowiązków pracowniczych, podejmując decyzje personalne, kierują się między innymi wyglądem zatrudnionego (tab. 6).

- W badanej grupie jest niemal czterokrotnie mniej decydentów, którzy, mimo że uważają, iż dbanie o wygląd ma negatywny wpływ na pracę zawodową, to kierują się w procesie oceny tym kryterium (1,3\%), niż tych, którzy dostrzegając negatywny związek pomiędzy dbałością o wygląd a realizacją zadań, podejmując decyzje personalne, nie biorą pod uwage prezencji pracownika (5,0\%) (tab. 6).

- Kierownicy uważający się za osoby zaangażowane w dbałość o własną prezencję przy podejmowaniu decyzji z zakresu rekrutacji, selekcji, wynagradzania, awansowania, szkolenia, oceniania czy zwalniania częściej biorą pod uwagę prezencję pracownika niż ci menedżerowie, którzy nie opisują siebie w kategoriach osób troszczących się o swój wygląd (tab. 7).

\section{Podsumowanie}

$\mathbf{P}$ rezencja, czego dowodzą przeprowadzone studia literaturowe, pełni szereg funkcji istotnych nie tylko z punktu widzenia człowieka, ale i organizacji, której jednostka jest członkiem. Dlatego też co drugi z respon- dentów „mocno” angażuje się w dbałość o własny wygląd i jest przekonany, że zaangażowanie to jest pozytywnie skorelowane $\mathrm{z}$ wywiązywaniem się z obowiązków zawodowych. Konsekwencją takiej opinii jest z kolei przeświadczenie połowy badanych kierowników, że powinni mieć oni możliwość wpływania na prezencję podległych im pracowników. Ponadto pomimo że w naukach o zarządzaniu podkreśla się konieczność stosowania obiektywnych kryteriów oceny wariantów rozwiązań, a humaniści apelują, iż utożsamianie człowieka $\mathrm{z}$ wyglądem i ocenianie na jego podstawie prowadzić może do wielu dysfunkcji (Ostaszewska, 2015, s. 200), to podejmowanie decyzji personalnych na podstawie prezencji nie jest obce praktyce organizacyjnej. Wykorzystywanie prezencji jako kryterium decyzji z obszaru zarządzania zasobami ludzkimi potwierdzają także wypowiedzi ponad połowy ankietowanych w badaniach własnych.

Uogólniając wyniki badań, stwierdzić można, że „wpisują się" one w twierdzenia dotyczące prezencji w zarządzaniu. Różnice w wypowiedziach ankietowanych kierowników i pracowników pokazują jednocześnie, że wygląd członków organizacji to temat drażliwy. Ingerowanie $\mathrm{w}$ prezencję podwładnych powinno więc przede wszystkim odbywać się w granicach obowiązującego prawa, szczególnie tego dotyczącego niedyskryminowania w zatrudnieniu. Rozumiejąc, iż menedżerom chcącym ingerować w prezencję pracowników przyświeca troska o dobro organizacji (jej pozytywny wizerunek, silną markę itp.), nie można zapomnieć, że coraz popularniejsza idea zróżnicowanych zasobów ludzkich organizacji zakłada konieczność kształtowania tzw. blended workforce, w której nie tylko akceptuje się, ale wręcz promuje heterogeniczność (także tą związaną z szeroko rozumianym wyglądem). Z punktu widzenia zarządzania ważne jest zatem, by w odniesieniu do prezencji kandydatów czy pracowników kierować się arystotelesowską zasadą „złotego środka”. W praktyce zatem, na przykład przy określaniu dress code, brać należy pod uwagę nie tylko stereotypowe 
przekonania dotyczące prezencji, ale i to, że współczesne społeczeństwa zachodnie indywidualizują się (Bauman, 2008, s. 66), a ich tolerancja dla odmienności zewnętrznej rośnie. Trzeba również monitorować, czy pracownicy zatrudnieni na różnych szczeblach organizacji nie mają uprzedzeń w stosunku do prezencji współpracowników oraz systematycznie organizować (szczególnie dla osób związanych z wypełnianiem funkcji personalnej) szkolenia poświęcone negatywnym skutkom stereotypizacji ze względu na wygląd (Nath i in., 2016, s. 2).

Choć przeprowadzone badania empiryczne mają ograniczenia (wynikające z nieprobabilistycznego doboru próby, pośredniej komunikacji z respondentami, zastosowania w kwestionariuszu pytań zamkniętych, potraktowania prezencji jako całościowego konstruktu, co uniemożliwiło analizę w odniesieniu do poszczególnych jego składowych), to uzyskane rezultaty stanowić mogą punkt wyjścia do dalszych, pogłębionych analiz związanych $\mathrm{z}$ rolą prezencji w zarządzaniu zasobami ludzkimi. Otrzymane wyniki skłaniają do postawienia kolejnych pytań badawczych:

- Które z elementów prezencji są najczęściej brane pod uwagę przy podejmowaniu decyzji kadrowych?

- W których subobszarach decyzyjnych z zakresu zzl prezencja jest najczęściej stosowana jako kryterium oceny, a w których najrzadziej?

- Na ile ograniczenia natury prawnej (np. te dotyczące zakazu dyskryminacji w zatrudnieniu) wpływają na (nie)kierowanie się wyglądem w procesie oceny?

- Czy (a jeśli tak - to w jakim stopniu) wirtualizacja funkcji personalnej zmienia rolę prezencji kandydata/pracownika w podejmowaniu decyzji kadrowych?

- Czy na skutek nasilających się procesów związanych z kultem pięknego, atrakcyjnego i ... wiecznie młodego wyglądu prezencja członków organizacji będzie coraz istotniejsza z perspektywy zarządzania?

Zdaniem autorki, postawione powyżej (wstępne) pytania badawcze są nie tylko interesujące, ale i aktualne. Jak podaje bowiem CBOS (Cybulska, 2017, s. 1-10), niemal $75 \%$ ankietowanych Polaków jest zdania, iż „dobra” prezencja jest predyktorem powodzenia w sferze życia zawodowego, przy czym jeden na trzech ankietowanych jest wręcz przekonany, że przesądza ona o sukcesie w pracy. Ponadto, na co zwrócono uwagę w pierwszej części artykułu, a co wymaga podkreślenia, choć sposoby ubierania się (będące przejawem mody) są przedmiotem rozważań takich wybitnych badaczy, jak Th. Veblen (1971) czy P. Bourdieu (2006), to nauki o zarządzaniu raczej tej tematyki nie eksplorują. A przecież strój, tak jak gesty, mimika czy pozycja ciała, jest jednym $\mathrm{z}$ aspektów komunikacji niewerbalnej, której rola w kierowaniu ludźmi jest niezaprzeczalna. Warto też zaznaczyć, że przywoływani wcześniej badacze z King `s College London (Nath i in., 2016), analizując rolę dress code i prezencji w miejscu pracy, posługują się terminem appearance management, który, choć dyskusyjny, wskazuje na istotność prezencji w zarządzaniu organizacją.

Biorąc pod uwagę powyższe, autorka ma nadzieję, że niniejszy tekst, wpisując się w ideę zarządzania zasobami ludzkimi i dyskusję o decyzjach kierowniczych, zainspiruje przedstawicieli nauk o organizacji do dalszych rozważań i badań nad rolą prezencji w zarządzaniu. dr hab. Katarzyna Wojtaszczyk, prof. uczelni

Uniwersytet Łódzki

Wydział Zarządzania

ORCID: 0000-0001-5120-735X

e-mail: katarzyna.wojtaszczyk@uni.lodz.pl

\section{Przypis}

1) W opracowaniu przyjęto, że synonimami zarządzania zasobami ludzkimi (zzl) są: funkcja personalna, funkcja kadrowa, zarządzanie personelem i zarządzanie kadrami; analogicznie - odpowiednikami decyzji z obszaru zarządzania zasobami ludzkimi są decyzje personalne oraz decyzje kadrowe.

\section{Bibliografia}

[1] Altkorn J. (1999), Wizualizacja firmy, Instytut Marketingu S.C., Kraków.

[2] Bauman Z. (2008), Zindywidualizowane społeczeństwo, GWP, Gdańsk.

[3] Bolesta-Kukułka K. (2003), Decyzje menedżerskie, PWE, Warszawa.

[4] Bourdieu P. (2006), Dystynkcja. Społeczna krytyka władzy sądzenia, Scholar, Warszawa.

[5] Cavico F.J., Muffer S.C., Mujtaba B.G. (2012), Appearance Discrimination, "Lookism" and "Lookphobia" in the Workplace, „The Journal of Applied Business Research”, Vol. 28, No. 5, pp. 791-802.

[6] Cybulska A. (2017), Czy jesteśmy zadowoleni ze swojego wyglądu? CBOS, Warszawa.

[7] Czaplińska P. (2015), Strategia budowania wizerunku osób znanych, [w:] A. Grzegorczyk (red.), Perswazyjne wykorzystanie wizerunku osób znanych, Wyższa Szkoła Promocji, Mediów i Show Businessu, Warszawa, s. 8-38.

[8] Dąbkowski G., Marcjanik M. (2002), Popularny słownik synonimów i antonimów, Wydawnictwo Wilga, Warszawa.

[9] Frederick D.A., Saguy A.C., Sandhu G., Mann T. (2016), Effects of Competing News Media Frames of Weight on Antifat Stigma: Beliefs about Weight and Support of Obesty-related Public Polices, „International Journal of Obesty”, No. 40(3), pp. 543-549.

[10] Gehrsitz M. (2014), Looks and Labor: Do Attractive People Work More? „Labour”, Vol. 28, No. 3, pp. 269-287.

[11] Giddens A. (2012), Nowoczesność i tożsamość. „Ja” i społeczeństwo w epoce późnej nowoczesności, Wydawnictwo Naukowe PWN, Warszawa.

[12] Hakim C. (2010), Erotic Capital, „European Sociological Review”, Vol. 26, No. 5, pp. 499-518.

[13] Hogan K., Labay M.L., Swaney J. (2007), Sztuka bycia atrakcyjnym. Sekrety osobistego magentyzmu, Helion, Gliwice.

[14] Holska A. (2016), Teorie podejmowania decyzji, [w:] K. Klincewicz (red.), Zarzadzanie, organizacje i organizowanie - przegląd perspektyw teoretycznych, Wydawnictwo Naukowe Wydziału Zarządzania Uniwersytetu Warszawskiego, Warszawa, s. 239-252.

[15] Jacko J.F. (2007), Proksemiczne strategie autoprezentacji, [w:] S. Lachiewicz, M. Matejun (red.), Problemy wspótczesnej praktyki zarządzania, Wydawnictwo Politechniki Łódzkiej, Łódź, s. 446-460. 
[16] Jakubowska A. (2008), Podejmowanie decyzji i problem ich optymalizacji, [w:] S. Piocha, R. Gabryszak (red.), Ekonomia menedżerska dla MSP w teorii i praktyce, Difin, Warszawa.

[17] Jakubowska H. (2009), Socjologia ciała, Wydawnictwo Naukowe UAM, Poznań.

[18] Joubert C., Stern S. (2006), Rozbierz mnie. Psychoanaliza garderoby, Jacek Santorski \& Co., Warszawa.

[19] Karaosmanoglu E. (2006), Determinants of Corporate Image Formation: A Consumer-Level Model Incorporating Corporate Identity Mix Elements and Unplanned Communication Factors, University of Warwick, Warwick.

[20] Kędziora K., Śmiszek K., Zima M. (red.), (2009), Równe traktowanie $w$ zatrudnieniu. Przepisy a rzeczywistość. Raport $z$ monitoringu ogłoszeń o pracę, Polskie Towarzystwo Prawa Antydyskryminacyjnego, Warszawa.

[21] Kosmala A., Wilk I., Kassolik K. (2019), Wptyw makijażu na samopoczucie i samoocenę u kobiet, „Pielęgniarstwo i Zdrowie Publiczne”, Nr 9(3), s. 215-220.

[22] Kościński K. (2007), Atrakcyjność twarzy: biologiczne podło$\dot{z}$ e, społeczne konsekwencje, „Academy of Aesthetic and Anti-Aging Medicine", Nr 2, s. 36-40.

[23] Kościński K. (2009), Atrakcyjność twarzy, https://www.researchgate.net/publication/266604273_Atrakcyjnosc_twarzy_2009/link/56746fa508ae0ad265ba7956/download, data dostępu: 14.01.2020 r.

[24] Krasnowolski A., Niedźwiedzki W. (1920), Stownik staropolski, Wydawnictwo M. Arcta, Warszawa, https://pl.wikisource.org/ wiki/M._Arcta_Słownik_Staropolski/P_(całość), data dostępu: $06.01 .2020 \mathrm{r}$.

[25] Król H. (2006), Podstawy koncepcji zarządzania zasobami ludzkimi, [w:] H. Król, A. Ludwiczyński (red.), Zarządzanie zasobami ludzkimi. Tworzenie kapitalu ludzkiego organizacji, Wydawnictwo Naukowe PWN, Warszawa, s. 50-91.

[26] Kujawska-Kot A. (2018), Ubiór i tożsamość. O znaczeniu odzieży dla bohaterów transplciowych, „Fabrica Societatis”, $\mathrm{Nr} 1$, s. 29-53.

[27] McLuhan M. (2004), Zrozumieć media. Przedłużenie człowieka, Wydawnictwa Naukowo-Techniczne, Warszawa.

[28] Mikołajczyk Z. (1994), Techniki organizatorskie $w$ rozwiqzywaniu problemów zarządzania, Wydawnictwo Naukowe PWN, Warszawa.

[29] Nath V., Bach S., Lockwood G. (2016), Dress Codes and Appearance Norms at Work: Body Supplements, Body Modifications and Aesthetic Labour, School of Management and Business, King's College London, London.

[30] Ostaszewska A. (2015), Psychoterapia integratywna w podejściu chrześcijańskim, GWP, Sopot.

[31] Paprzycka E., Orlik D. (2015), Czy wygląd ma znaczenie? Kapitat seksualny a sukces rekrutacyjny w opiniach kobiet i mężczyzn, „Acta Universitatis Lodziensis. Folia Sociologica”, Nr 55, s. 5-21.

[32] Rosen-Przeworska J. (1948-1949), Społeczna funkcja odzieży, „Światowid”, Nr 20, s. 297-318.

[33] Sajkiewicz A. (red.), (1999), Zasoby ludzkie w firmie: organizacja, kierowanie, ekonomika, Poltext, Warszawa.

[34] Skwarska A. (2019), Polacy o Dress Code w pracy. Od garsonki po trampki, http://media.pracuj.pl/65472-polacy-o-dress-code-w-pracy-od-garsonki-po-trampki, data dostępu: 01.02.2020 r.

[35] Slepian M.L., Ferber S.N., Gold J.M., Rutchick A.M. (2015), The Cognitive Consequences of Formal Clothing, „Social Psychological and Personality Science", Vol. 6, No. 6, pp. 661-668.
[36] Smith A. (1989), Teoria uczuć moralnych, PWN, Warszawa.

[37] Sobczak I., Smith J. (2016), 9 błędów dotyczacych ubioru i higieny, które moga wstrzymać twój awans, https://businessinsider. com.pl/lifestyle/savoir-vivre/dress-code-najczesciej-popelniane-bledy/ghhe734, data dostępu: 28.01.2020 r.

[38] Sobocka-Szczapa H. (2014), Dobór pracowników - decyzja strategiczna firmy, „Zeszyty Naukowe Politechniki Śląskiej. Seria: Organizacja i Zarządzanie", Nr 68, s. 103-115.

[39] Strzelecka A. (2002), Płeć i zachowanie - jeszcze jedno pytanie o różnice, [w:] A. Kuczyńska (red.), Zrozumieć pleć. Studia interdyscyplinarne, Wydawnictwo Uniwersytetu Wrocławskiego, Wrocław.

[40] Szcześniak-Kosiorek D., Fryzura i makijaż w biznesie, https:// www.dskconsulting.pl/fryzura-i-makijaz-w-biznesie/, data dostępu: 17.01.2020 r.

[41] Szymaniak-Kostrzewska A. (2016), Co oznacza atrakcyjność fizyczna? Dyskusja o definicjach i ujęciach, „Roczniki Psychologiczne/Annals of Psychology", Vol. 19, Nr 1, s. 43-74.

[42] Szymoniuk B. (2011), Wizerunek biznesowy w procesie komunikacji marketingowej, „Zeszyty Naukowe Uniwersytetu Ekonomicznego w Poznaniu", Nr 209, s. 442-451.

[43] Trzeciak S. (2015), Coaching marki osobistej czyli kariera lidera, GWP, Gdańsk.

[44] Tylka J. (2012), Zdrowie menedżera. Styl życia a zdrowie i choroba, Difin, Warszawa.

[45] Veblen T. (1971), Teoria klasy próżniaczej, PWN, Warszawa.

[46] Wojciszke B. (2002), Człowiek wśród ludzi. Zarys psychologii społecznej, Wydawnictwo Naukowe Scholar, Warszawa.

[47] Wrzalik A. (2013), Zastosowanie wybranych rozwiązań informatycznych $w$ procesie rekrutacji i selekcji personelu, „Przegląd Organizacji”, Nr 9, s. 45-50.

[48] Zbiegień-Maciąg L. (1999), Kultura w organizacji. Identyfikacja kultur znanych firm, Wydawnictwo Naukowe PWN, Warszawa.

\section{Presence as a Criterion for Personnel Decisions}

\section{Summary}

The aim of the paper is to show the essence of presence, its role as a criterion for decision in human resource management. Two research methods have been used to achieve the goal: (1) literature studies, (2) surveys carried out among 1002 managers and 1000 non-managerial employees. Literature studies and results of empirical research have shown the following: presence has a number of functions that are important not only from the point of view of a human being, but also of the organisation; making managerial decisions based on presence is not unknown to organisational practice. More than 50\% respondents confirmed that presence is used as a decision criterion. Almost the same percentage of respondents believe that the employee's care for appearance favours the fulfilment of tasks and official duties. In addition, half of the managers surveyed would like to have the right to intervene in matters related to the presence of employees.

\section{Keywords}

presence, decisions, personnel management 